\title{
AGAINST THEORETICAL EVANGELISM: IMAGINING THE POSSIBILITIES OF A CRITICAL APPROACH TO THEORISING IN PROFESSIONAL ACADEMIC DEVELOPMENT
}

\author{
K. Naidoo \\ Professional Academic Staff Development \\ University of Johannesburg \\ Johannesburg, South Africa \\ e-mail: knaidoo@uj.ac.za
}

\section{ABSTRACT}

This article contributes to dialogue on theorising in higher education, with particular reference to professional academic development. It provides a critique of the evangelical adherence to dominant theories and argues that their uncritical use cannot contribute to addressing social injustices in higher education. It also argues for theorisation in professional academic development that is more sensitive to context. Drawing on insights from C. Wright Mills (2000), the article suggests that, by viewing theorisation through the lens of a sociological imagination, it is possible to engage critically with dominant discourses and come up with creative solutions that are aligned with a viewpoint that promotes social justice in professional academic development, as well as addressing social inequities and injustices in higher education.

Keywords: professional academic development, social justice, sociological imagination, contextsensitive theory, theorisation

\section{INTRODUCTION}

Everyone who can think, can ultimately also theorise; and the project of theorising therefore is inherently democratic. (Kant [1784] 1970)

The idea of theorising as inherently democratic is an appealing one, as is the idea that it is possible for everyone to theorise. Yet in academia theory can be intimidating, and is often a space fraught with anxiety rather than one that engenders hope and creativity. It is also ironic that, given the potential for everyone to theorise, very little of this theorisation is recognised as legitimate in academic circles; often, the theory that is valued is understood by only a small cadre of academics. Consequently, theory is often accorded the authority to exclude and silence. The need for theory and the importance of engaging with it in professional academic development research and practice is not questioned here: I do not believe that we can address social problems and function as effective professional academic practitioners without 
theorising. What is questioned is the uncritical, almost evangelical, use of theory which prevents professional academic developers from thinking of creative solutions to the social injustices that are prevalent in higher education. It is not within the scope of this article to explore in depth the role of theory in higher education, as this has been discussed exhaustively in, for example, the 2012 special edition of Higher Education Research and Development (Trowler 2012).

This article, which is located in the on-going discussion on the role of theory in higher education (see, for example, Trowler 2012; McArthur 2012; Clegg 2012), argues for greater consideration of context in theorising in the field of professional academic development. It draws on Wright Mills' idea (2000) of the sociological imagination, which provides a useful way of exploring the interplay of private troubles and public issues, and related concerns for theory and practice. In this article, I explore the possibility of developing an approach to theorising that allows for the development of a sociological imagination in professional academic development - one that has the characteristics of a critical approach.

I begin by examining theory and theorisation in professional academic development. After that, key ideas relating to the sociological imagination are explored and ways in which they can be applied to enhance theorisation are illustrated by drawing on examples in education and the social sciences. The article ends by extending the idea of the sociological imagination in order to develop some key considerations that can help us to theorise in professional academic development.

\section{THEORY IN ACADEMIC DEVELOPMENT}

There is no doubt that professional academic developers have to engage with theory. As Scott (2009) rightly points out, the 'craft knowledge' approaches to solving problems in higher education, which are still prevalent in many institutions, are not sufficient. Instead, he maintains that what is required is more 'systematic knowledge' of teaching and learning, and of theory and practice:

The key limitation of craft knowledge is that, lacking a systematic or theoretical base, it does not provide conceptual or analytical tools for dealing with 'non-traditional situations .... The new educational challenges in higher education call for research-based and scholarly approaches to be brought to bear on teaching and learning practices .... (Scott, Yeld and Hendry 2007, 61).

It must be acknowledged that academic development, internationally and in South Africa, is shifting from being primarily 'atheoretical, based on common sense or intuition' (Leibowitz 2016, 156). A review of the Higher Education Learning and Teaching Association of Southern 
Africa (HELTASA) conference proceedings in the last five years reveal that a larger number of academic developers in South Africa were engaging in research and were drawing on a range of theories to inform their practice. For, example many professional academic developers have drawn on critical realism as a meta-theory and on Margaret Archer's social realism to explore the interplay of structure, culture and agency in professional academic development. Others, working in the realm of curriculum development, have used the sociology of education and the work of Bernstein to frame their research and practice. The work of Tinto on persistence has also been evident and has been applied to the exploration of factors that contribute to student development inside higher education institutions.

While these are positive shifts in academic development, the predominance of approaches and theories from the global north (Leibowitz 2012) is troubling, as these theories and approaches tend to be applied in an uncritical and unproblematised way. It is important to be critical because theories and approaches that originate in the global north do not always account adequately for multifaceted socio-political contexts or for related pedagogical and curriculum challenges.

This raises questions about the relevance and appropriateness of approaches and theories that have been developed in other contexts to solving local problems. Similar questions were raised in recent student protests within South African higher education around the relevance of knowledge that emanates from the global north for students in the south and the extent to which this knowledge could alienate particular groups of students. These events served to stimulate important debate and discussion on curriculum transformation. Amidst calls to fight against 'epistemic coloniality', which refers to the endless production and appropriation of theories that are situated within European tradition (Mbembe 2015), it is timeous that the editors of this issue have called for articles that pay greater attention to context. Paradoxically, the fact that many of the authors referred to in this article are from the global north could be seen as exacerbating the domination discussed above. In response, I contend that the argument against the uncritical use of dominant theories and the importance of theories that are sensitive and relevant to context does not preclude me from drawing on perspectives from the global north. Furthermore, this article does attempt to engage critically with all the literature and theories cited in the article those emanating from both the global north and the global south.

It is important to acknowledge that there are exceptions and that some academic developers have drawn on perspectives from both the global north and south in order to confront questions concerning the relevance of knowledge as well as to ensure that disciplinary knowledge and discourses are accessible to students. Reeler's (2015) work on epistemic 
disobedience presents an interesting illustration of this. Reeler (2015) is an academic developer who works in a research-intensive university in South Africa. In her practice, she sought to deliberately

... interrupt the traditional knowledge hierarchies present in South African universities. Such content was defined as that which consciously aimed to engage with African epistemologies, be it through teaching postcolonial theory, deconstructing dominant canons or worldviews; using African examples, texts and contexts; correspondent examples or theories from other parts of the so-called third world or a pedagogy that used African languages as learning resources. (Reeler 2015, 1)

Reeler uses a Bernsteinian lens of knowledge structure and Mignolo’s (2011) decolonial thinking to inform her practice and develop curricula that were more relevant to the student experience and context. Bernstein provides a useful lens for examining the ways in which knowledge is structured in disciplines (Reeler 2015). Mignolo’s work (2011) on decolonial thinking provides a useful way of examining the importance and value of local knowledge. He advocates changing the terms of the conversation and the content and going back to the reservoir of ways of life and thinking that were often dismissed by western theories.

Reeler's (2015) article is interesting in that it elucidates the usefulness of drawing on multiple perspectives. In addition, decolonial thinking provides her with an appropriate theory to help her explain and justify her practice and explicitly address questions of relevance of knowledge. Reeler's (2015) work also raises important questions about the possibilities of decolonial thinking serving as a theoretical lens to help academics address the challenge, raised in the recent student protests, of the need for curriculum transformation in South African higher education. At the heart of this challenge is the need for academics to consider the political nature of their work and the ways in which their practices and related theories include or exclude individuals or groups. While there is value in exploring multiple perspectives and drawing on a number of different theories that originate in different contexts, it is important to interrogate these theories in terms of their applicability to practice and context.

The call for some researchers to draw on southern theories (Connell 2007) in order to address questions concerning the relevance of theory to context is not a new one. Connell (2007, 244), for example, who is critical of approaches that originated from the north, provides an argument for theories from the south, or periphery. She points out that theories and contributions from the south are valuable and have something unique to offer. To quote Connell (2007, 244), 'social science in the periphery also ... injects themes that are relatively uncommon in metropolitan thought'. While southern theories could contribute to theoretical enrichment, there are problems with this argument as it is based on the assumption that all knowledge from 
the north is dominant and all southern knowledge is powerless. Whilst it is important to challenge northern hegemonic theories and knowledge systems, emphasis on southern theories could result in the dismissal of excellent research as being irrelevant by virtue of where it comes from. Theories are not automatically relevant because they emerge from a particular context and one has to caution against the replacing of dominant theories from the north with those from the south.

\section{Fashionable theory}

When a version of this article was presented at the Professional Development Colloquium in July of 2015, a colleague expressed the concern that, over the years, professional development practices and research have been informed by a series of approaches and theories; because these approaches were adopted by those who were considered experts in the field, it was expected that practitioners should become familiar with these dominant trends and follow them. As I have stated above, it is important for academic developers to engage with theory and with what is emerging as powerful knowledge in the field. But appropriation without critical engagement with that knowledge, and with little concern for the actualities of context is of limited value, both in finding solutions and in terms of enriching theory in academic development. Ashwin (2012) expressed a similar view in relation to research into higher education in general, when he said that research seemed to move through a succession of theoretical lenses, the use of which appeared to be a matter of fashion and not necessarily of extending theories.

Ball (2006a) also cautioned against the uncritical use of theory, arguing that 'theory can, and often does, function to provide comforting and apparently stable identities for beleaguered academics in an increasingly slippery world’. He went on to argue that

Theory can serve to conjure up its own anterior norms and lay its dead hand upon the creativity of the mind. Too often in educational studies, theory becomes no more than a mantric reaffirmation of beliefs rather than a tool for exploration and for thinking otherwise. (Ball 2006a, 64)

This mantric use of theory, or 'theoretical evangelism' as I refer to it, does not offer the possibilities of seeing things in new ways and of stimulating the imagination. From a cynical viewpoint, one may say that, at best, the evangelical use of theory offers words by which to describe structures and situations.

In the series introduction to Anyon's (2009) book Theory and educational research: Towards critical social explanations, Dimitriadis attributes the uncritical engagement with theory in higher education internationally to economic needs and neo-liberal thought. He suggests that we have recently witnessed a full-scale assault on the 'research imaginary' in 
many academic disciplines, especially education (Dimitriadis in Anyon 2009). Economically driven and ranking demands on higher education have effectively diminished thoughtful engagement with and between theory and research and between theory and practice. Higher education research agendas have been driven by the need to find quick solutions and practices that work and can be easily replicated. This need is exacerbated by an increased focus on throughput rates and quantifiable performance management criteria in South Africa and internationally. The latter often result in the evaluation of staff against predetermined criteria which obscure crucial aspects like developmental and innovative educational and pedagogical practices (Clarence-Fincham and Naidoo 2014) - exactly the spaces within which many professional academic developers work. In response to this, researchers resort to imposing theory onto a problem in order to find quick, easily-implemented solutions rather than exploring the problem in depth and examining the structures, processes and social relations that contribute to it (Dimitriadis in Anyon 2009).

\section{Theory as a tool for thinking otherwise}

Theory, in professional academic development which is aimed at addressing social injustice, should serve not only to describe and explain practice, but also change it. In this sense, the process of theorising is both creative and emancipatory (Trowler 2012). An approach to theory that aims to transform the status quo and address social injustices has the potential to critique dominant discourses, ensure that silent voices are heard and become more inclusive. According to Ball (1995, 265-266), theory is a vehicle for 'thinking otherwise', it is a platform for 'outrageous hypotheses' and for 'unleashing criticism'. He further argues that theory can provide a 'language for challenge and modes of thought other than those articulated for us by dominant others’ (Ball 1995, 265-266).

Theory is also political, not only because it carries a point of view but also because the employment of theory can be used to promote particular agendas. As Britzman (2012, 44) points out, 'the audacity of theory contains a kernel of aggression and seeks to either destroy old views or protect them from changing; theory is not benign'. Theory can be used in both conservative and transformative ways and can result in either maintaining the status quo or in transformation which could address social inequities. In this sense, theories do not have a fixed political meaning. Said (1983) argued that when theories move from one context to another, their meanings can be transformed in a radical or conservative direction. Theories can take on different implications depending on where, when and how they are being used. For example, conservative theories can be used in more transformative ways when translated into a different 
context (Burawoy 2015). Burawoy (2015) cites the example of how academics in South Africa used theory associated with the functions of conflict (conservative theories) against the apartheid state to illustrate this point. Thus, theories can be used in ways that are counter to their original intention.

Given the fluidity of theory and the importance and fluidity of the context within which theory is applied, perhaps more emphasis should be placed on theorising as an active process rather than on theory as a lens through which to view the world.

\section{Theory use versus theorising}

When we engage with theory, we need to remember that we do not do so for its own sake and that we do not revere theory to the extent that we feel it cannot be criticised or used in more innovative ways. Some theorists encourage their readers to engage more critically and interactively with their work. Ball (2006b) cites the example of Bourdieu, who wanted readers to read his works as 'exercise books' rather than as theories. In other words, he wanted readers to participate in his work, not merely to appropriate it. In this sense, the process of engaging theory is an active and a deeply reflective scholarly process. hooks $(1994,70)$ is more explicit in her endeavour to invite readers to engage with and critically reflect on her work in feminist theory:

Reflecting on my own work in feminist theory, I find writing -theoretical talk - to be most meaningful when it invites the reader to engage in critical reflection and to engage in the practice of feminism.

Swedberg (2014) also contends that in order to end up with better theory, we need to shift our main concern to theorising. For him, theorising is a creative yet practical process of producing theory. In terms of engaging theory, Clegg (2012) also suggests that rather than an emphasis on theory we need to think about theorising as a process. But she does not explicitly unpack how we can theorise and what the process of theorising might entail. In her discussion of her own work, it becomes apparent that for her (Clegg 2012), the process of drawing on different theorists in order to explain emergent themes in the data, themes that were not evident in the theory that she had begun her research with, constitutes theorising. Drawing on Wright Mills' notion of intellectual craftsmanship, Clegg (2012) explicates how she goes about assembling the theoretical tools that helped her think through research problems. In relation to this article, however, the notion of theorising needs to be extended to include the ways in which it can contribute to transformative practice which in turn could extend and result in theory that is more sensitive to the socio-historical and political context within which practice is located. 
Like Clegg (2012), I also return to my sociological roots and draw, more broadly, on the sociological imagination as a heuristic to help think about theory in professional academic development.

\section{THE SOCIOLOGICAL IMAGINATION AND THEORISING IN PROFESSIONAL ACADEMIC DEVELOPMENT}

... the sociological imagination is not merely fashion. It is a quality of mind that seems most dramatically to promise an understanding of the intimate realities of ourselves connected with larger social realities. (C. Wright Mills 2000, 15)

The sociological imagination is a scholarly project and offers a way of being for academics working in the social sciences and education. Even though it was written more than 50 years ago, much of C. Wright Mills' critique of developments in the society and in the social sciences holds true today.

There are three important, inter-related ideas inherent in the sociological imagination that I see as being especially relevant to this article. The first is the notion of the sociological imagination as a state of mind that turns personal problems into public issues. Second, and related to this, is the importance of moving from personal and familiar cultural experiences, stepping back and viewing one's own society as an outsider would. Third is his consideration of values which inform both sociology and society.

\section{From personal problems to public issues}

C. Wright Mills (2000) was critical of both the grand theory and the abstracted empiricism that began to dominate the social sciences and sociology, in particular. His criticism of grand theory, particularly the work of functionalists like Talcott Parson, is that 'it outruns any specific and empirical problem. It is not used to state more precisely or more adequately any new problem of recognizable significance' (Wright Mills 2000, 48). Wright Mills argued that the problem with grand theory is that it is so general that its reference to and connection with actual observation (data) and practice is obscure. He suggested that instead of grand theory one needs theory that is located more firmly in the historical and structural milieu. Given the constantly changing nature of this context, such theory is inevitably tentative, fallible and dynamic. Wright Mills (2000) proposed the idea of the sociological imagination as a way of examining the relationship between the personal troubles of individuals (what we might refer to as agents) and the public issue of social structure. This interplay of personal troubles and public issues is conveyed in his conception of the sociological imagination as 'the awareness of the relationship 
between experience and the wider society' (Wright Mills 1959, 3).

This is a key idea in developing context-specific social theory aimed at transforming individuals and society. Its usefulness for professional academic development is that it speaks to the value of relating personal challenges that individual practitioners encounter to the micro as well as to the macro structural, cultural and historical context. Theorising, for Wright Mills (2000), will involve a process whereby individual (or collective) practices are understood in terms of the intersection between personal troubles or biographies and histories and public issues or structures. Theorising occurs in different contexts and for different purposes (Trowler 2012). In order to theorise with a redress and transformation agenda, it is imperative that professional academic developers examine the ways in which private troubles (biography) intersect with public issues and history to produce desired outcomes.

As academic developers, we are often asked to provide 'quick solutions' to help teachers 'do things better' so that students can pass. This is reminiscent of the neoliberal, managerialist project discussed earlier, where academic developers are expected to get the most done for the least amount of money, in the shortest time. Very often these are 'tips for teachers' that work in one context and are expected to be equally successful when transferred to other contexts.

There are a number of problems with this approach. Those of us working in academic development know that the problems that we encounter and are asked to fix are complex and that the 'quick fix', decontextualised 'tips-for-teachers' approach is not the solution to the problem. The fact that this does not account for the specificities of the context and the interplay of individual efforts and structural enablements that contribute to this success is perhaps one of the biggest problems. These approaches do not often contribute to transformative practice. An approach that is more aligned with the sociological imagination is one suggested by Sfard (2013). She proposes discursive research where researchers and practitioners dig deep under the familiar and the obvious, looking for unsuspected but highly consequential differences; rather than trying to tell teachers what is going to work in their classrooms, the researcher should help them craft tailor-made solutions for their specific problems. Theorising in this approach involves engaging with and accounting for the complexities of the political, historical, social and political contexts. Rather than conform to the demands of institutional leaders and politicians, this approach could be considered radical in that it seeks to transform practice through participative processes.

As professional developers who work with academic staff, we are often asked by the academic staff who are discipline specialists for references to the dominant theories, to help them craft their teaching philosophies. In these instances, academics are not questioning that 
theory was important to demonstrate scholarly engagement in teaching and learning. However, they fail to see theorising practice as a process of learning to become scholars of teaching and learning in their discipline or fields of practice, which in turn informs practice. I want to suggest that our practices are never atheoretical. We may not start with a well-articulated theoretical approach but we all approach practice with a set of values or beliefs that inform the approach that we take. It is crucial that academics and academic developers enter into dialogue with their practice context before imposing a definitive theoretical lens on it. This includes the actual experience of the participants in their disciplinary, as well as their socio-cultural and historical contexts. The dialogue between biography or personal experience and socio-historical context has to be ongoing, as should the dialogue between theory and practice. Dialogue between theory and practice or context is important for the enrichment of theory.

Along similar lines, Smith (2005) critiques mainstream sociology because it does not pay sufficient attention to the actual lived experience of the research participants. In her work on institutional ethnography, she attempts to address this. She suggests starting with the actualities of people's lives and argues that research be viewed as discovery rather than explication of theory or as analysis of empirical data. She argues for the importance of expanding on peoples' knowledge rather than narrowing it down by framing it within a particular theoretical lens. This limits the possibilities of imaginative solutions. When academics begin with a theory, and then use interview quotes and observations as illustrations of the categories and concepts, the problem is viewed through a lens which restricts possibilities. The experiences and actualities of the lives of people are selectively explored. This raises the question of whether research data or practices would look different if we did not start with theory. Theorising, as described here, is more emergent and tentative. It also, importantly, brings the actualities of peoples' experiences into dialogue with theories. As academic developers, it is important to embrace the tentativeness of our understanding of the world.

\section{Viewing daily practices anew}

In order to think about and develop novel and innovative practices, it is imperative that the social, political and cultural contexts are taken into consideration. This requires that we take a step back from our daily practices, look at them anew and question them. Wright Mills suggested that, in order to address social problems, people need a way of thinking that will help them to use information and 'to develop reason in order to achieve lucid summations of what is going on in the world and of what may be happening within themselves' (Wright Mills 2000, 5). They need to ask questions like: How are daily practices shaped by and how do they shape 
the policy and institutional context in which they occur?

While Wright Mills proposed a process of distancing in order to see problems more clearly and there is value in that, he was not suggesting that academics are not engaged. We do need to caution that in stepping away from individual experience to broader society and in exploring the relationship between the individual and society we must not forget, as Sayer (2011) points out, that which matters to people. Sayer $(2011,6)$ cautions:

... it seems that becoming a social scientist involves learning to adopt this distanced relation to social life, perhaps so as to be more objective, as if we could become more objective by ignoring part of the object. It therefore often tends to produce bland accounts of social life, in which it is difficult to assess the import of things for people.

The challenge for professional academic developers is to be immersed in the messiness of the real-life context without being so bogged down in the quagmire that we cannot open ourselves to alternative possibilities and be imaginative. Thus, the importance of thinking ourselves away from the familiar does not imply disengagement but provides space to broaden the lens to enable it to be more imaginative. This stepping back provides a catalyst for change by making it possible to become acutely aware of the dynamic social contexts within which our practices are located. This is particularly important in professional academic development, where we can sometimes become complacent and our practices can become routine. There is comfort and safety in this. But the dynamic nature of professional development work requires that we embrace it with the discomfort and interruption that comes with this dynamism. If we do not, our practices become mantric or routine and our discourses become evangelical - uncritical and unchanging. Furthermore, critique of theory has to be linked to practice; if not, critique remains rhetorical and does not result in transformation of structures and practices.

It is important to point out that even though Wright Mills (2000) acknowledged that criticism is not only the responsibility of public intellectuals (Giroux, 2015), he has been criticised for the emphasis he placed on the role of academics who work in an insular way from the rest of society (Burawoy 2008). Following Burawoy, I believe that academic developers, and social scientists in general, have to engage in dialogue with both the academic as well as the broader community. This is important for understanding the ways in which both individual and collective actions can contribute to change. A crucial aspect of this is dialogue with the theories that inform our research and practice.

Dialogue is difficult because knowledge is not equally valued. Soudien $(2014,916)$ raises this concern when he asks:

How does dialogue begin which is able to engage with the best that is known in this context and 
which does not by definition position knowledge either favourably or negatively simply by virtue of where it comes from?

I argue that rather than dismissing theories that originate from another context, an important element of dialogue is critical engagement. We ought to step back and ask questions about the theories that we are using, about the links between power and the production of the theories we are reading and about their relevance. We also need to consider the possibility that these theories do not provide an adequate explanation of what is actually happening and consequently cannot help in addressing social problems.

\section{Values}

Wright Mills $(2000,130)$ argued that in the formulation of problems it is important to clearly articulate 'the values that are threatened in the troubles and issues involved, who accepts them as values, and by whom or by what they are threatened'. He believed that the research questions that social scientists address should go beyond an understanding of what is to a concern for what ought to be. What ought to be is entrenched in the values that inform social science - those of freedom and reason, which in my reading of Wright Mills involves critique. He believed that bureaucratic social science, which is similar to the audit culture that we see in higher education, in which the 'social science endeavor has been pinned down to the services of prevailing authorities' (Wright Mills 2000, 129), threatens these values. In addition to grand theory, what he referred to as 'abstract empiricism', the large survey-type research, was a key feature of bureaucratic social science. This type of research was driven by profit and did not aim to advance learning. He argued that the problem with this was its focus on individual opinion and the fact that it did not include consideration of the structural, political and historical context which influences opinion. A further criticism related to the fact that this type of research did not necessarily address real social problems and tended to be atheoretical. He conceded that, when reference is made to theory in large-scale empirical research, its role is merely to justify the study. He argued that literature is often consulted independently of the actual empirical study by an assistant who produces a literature review memorandum which 'is reshaped in an effort to surround the empirical study with theory ... to get a better story out of it' (Wright Mills $2000,69)$. This is contrary to the values of reason and freedom. These values were important in the prevailing socio-political context at the time when Wright Mills (2000) wrote. However, in the light of the higher education context outlined earlier in this article, I think that, in addition to reason and freedom, another value that ought to inform our practice as activist professional developers should be social justice, especially as it encompasses notions of access and equality. 
This is aligned with Wright Mills' (2000) belief that the research questions that social scientists analyse must not only be concerned with what is, but with what ought to be.

Theorising is not merely about finding solutions to problems. More crucially, it is about stepping back and asking questions of the theoretical lenses that we use. Wenger-Trayner (2013) argues with regard to practice-based research in education that all researchers (and practitioners) must ask themselves the following question:

- Which theory is most appropriate given my data (or problem), the methodology I am using and the story that I am telling?

In addition to the above, other questions may include:

- $\quad$ Does one theory adequately tell this story?

- To what extent are the theoretical lenses aligned with the values of reason, freedom and justice?

- Am I, in the process of theorising, engaging dialogically?

In the next section of this article, I build on Wright Mills' ideas by translating them into broad ideas that we may find useful in thinking about professional academic development in the South African higher education context.

\section{APPLYING A SOCIOLOGICAL IMAGINATION}

From the idea of the sociological imagination, I have developed three key considerations relating to theorising in professional development. The first principle is to critically explore the practice and/or research context in order to develop an understanding and critique of the dynamic interplay between private troubles we face our classrooms, or units, and the public issues, the structural constraints and enablements. Second, we need to step back and ask questions of the theoretical lenses we use in our practice and avoid unquestioning strict adherence to one theory. In other words, we need to enter into dialogue with theories, not just the fashionable ones. We ought to bring theories into dialogue with the practice or research context and use practice as our craft to engage more critically with theory. This may contribute to enriching theory and sparking debate. Third and perhaps most importantly the values of social justice, critique and freedom should inform theory and practice. 


\section{CONCLUSION}

I began this article with a quotation from Kant, who suggested that theorising is an inherently democratic process in that anyone can theorise. For academic developers, their practice provides an exciting space for theorising. In this context, theorising ideally means connecting theory and practice so that experience/practice becomes our intellectual work in higher education. I suggested that the idea of the sociological imagination, which is quality of mind that turns personal troubles into public issues, speaks powerfully to the importance of context in theorising professional academic development. This is crucial for critique and emancipatory practice. I argued that rather than feeling compelled to engage with fashionable theories, we need to bring theory into dialogue with context, challenge or question theories with the lived realities of our context and the extent to which they can help us solve problems in our context. We also need to problematise things that are taken for granted - that originate from another context - which we normally engage with uncritically because of their dominance. And importantly, we should avoid closure and acknowledge the tentativeness and temporality in our theories and that as our context changes, so too will our practice, and of necessity, so too will our theories. This will help us extend theories and, more importantly, develop more socially just practices.

\section{ACKNOWLEDGEMENT}

I acknowledge the support of the National Research Foundation (NRF) funded project entitled 'Structure, Culture and Agency', grant number 74003 for funding to attend the colloquium on Contextual Approaches to Professional Academic Development with regards to the Teaching Role, at which a version of this article was presented.

I am indebted to my colleagues Vanessa Merckel for her insightful comments on the numerous iterations of this article and for coining the phrase theoretical evangelism which appears in the title, as well as Brenda Leibowitz for her invaluable feedback.

\section{REFERENCES}

Anyon, J. with M. Dumas, D. Linville, D. Nolan, M. Perez, E. Tuck, and J. Weiss. 2009. Theory and educational research: Toward critical social explanation. New York and London: Routledge.

Ashwin, P. 2012. How often are theories developed through empirical research into higher education? Studies in Higher Education 37(8): 941-955.

Ball, S. J. 1995. Intellectuals or technicians? The urgent role of theory in educational studies. British Journal of Educational Studies 43: 255-271.

Ball, S. J. 2006a. Education, policy and social class: The selected works of Stephen J. Ball. London and New York: Taylor and Francis.

Ball, S. J. 2006b. The necessity and violence of theory. Discourse: Studies in the Cultural Politics of 
Education 26(1): 3-10.

Britzman, D. P. 2012. What is the use of theory? A psychoanalytic discussion. Changing English 19(1): 43-56

Burawoy, M. 2008. Open letter to C. Wright Mills. Antipode 40(3): 365-375.

Burawoy, M. 2015. Travelling theory. Open Democracy. https://www.opendemocracy.net/Michaelburawoy/travelling-theory (accessed 29 September 2015).

Clarence-Fincham, J. and K. Naidoo. 2014. Translating theoretical perspectives into constructive debate: Recontextualising the curriculum in the South African context. South African Journal of Higher Education 28(3): 1003-1016.

Clegg, S. 2012. On the problem of theorising: An insider account of research practice. Higher Education Research and Development 31(3): 407-418.

Connell, R. 2007. Southern Theory: The global dynamics of knowledge in social sciences. Cambridge. Polity.

Giroux, H. A. 2015. Higher education and the politics of disruption. Truthout. www.truth-out.org/ news/item/29693-higher-education-and-the-politics-of-disruption (accessed 3 April 2015).

hooks, b. 1994. Teaching to transgress: Education as the practice of freedom. New York and London: Routledge.

Kant, I. [1784] 1970. An answer to the question: 'What is enlightenment?' In Kant's Political Writings, ed. H. Reiss, 54-60. New York: Cambridge University Press.

Leibowitz, B., ed. 2012. Higher education for the public good: Views from the south. Staffordshire: Trentham Books in association with SuN MeDIA.

Leibowitz, B. 2016. The professional development of academics as teachers: Reconsiderations. In Investigating higher education: A critical review of research contributions, ed. J. Case and J. Huisman, 153-170. London: Routledge/SRHE.

Mbembe, A. 2015. Decolonising knowledge and the question of the archive. Public lecture. Wits Institute for Social and Economic Research. University of Witwatersrand. Johannesburg. http://wiser.wits.ac.za/system/files/Achille\%20Mbembe\%20-\%20Decolonizing\%20Knowledge \%20and\%20the\%20Question\%20of\%20the\%20Archive.pdf (accessed 1 March 2016).

McArthur. J. 2012. Virtuous mess and wicked clarity: Struggle in higher education research. Higher Education Research and Development 31(3): 419-430.

Mignolo, W. 2011. The darker side of western modernity: Global futures, decolonial options. Durham and London: Duke University Press.

Reeler, S. K. 2015. Steps towards decolonial higher education in South Africa? Researching epistemic disobedience in the postcolonial humanities. Paper presented at CODESRIA 14. Creating African Futures in an Era of Global Transformation: Challenges and Prospects. Senegal. 8-12 June 2015. http://www.codesria.org/spip.php?article2343 (accessed 1 April 2016).

Said, E. 1983. 'Travelling theory'. The world, the text, and the critic. Cambridge. MA: Harvard UP.

Sayer, A. 2011. Why things matter to people: Social science, values and ethical life. New York: Cambridge University Press.

Scott, I., N. Yeld and J. Hendry. 2007. A case for improving teaching and learning in South African Higher Education. Higher Education Monitor No 6. Pretoria. Council on Higher Education.

Scott, I. 2009. Academic development in South African higher education. In Higher education in South Africa: A scholarly look behind the scenes, ed. E. Bitzer, 21-49. Stellenbosch. South Africa: SUN MeDIA.

Sfard, A. 2013. Not just so stories - practicing discursive research for the benefit of educational practice. In Reframing educational research: Resisting the 'what works' agenda, ed. V. Farnsworth and Y. Solomon, 139-150. Abingdon. Routledge.

Smith, D. E. 2005. Institutional ethnography: A sociology for people. Oxford: Altamira Press. 
Soudien, C. 2014. 'Inclusion, innovation and excellence: Higher education in South Africa and its role in social development'. South African Journal of Higher Education 28(3): 907-922.

Swedberg, R., ed. 2014. Theorising in the social sciences: The context of discovery. California: Stanford University Press.

Trowler, P. 2012. Wicked issues in situating theory in close-up research. Higher Education Research and Development 31(3): 273-284.

Wenger-Trayner, E. 2013. The practice of theory: Confessional of a social learning theorist. In Reframing educational research: Resisting the 'what works' agenda, ed. V. Farnsworth and Y. Solomon, 105-118. Abingdon. Routledge.

Wright Mills, C. 1956. The power elite. New York: Oxford University Press.

Wright Mills, C. 1959. The sociological imagination. New York: Oxford University Press.

Wright Mills, C. 2000. The sociological imagination: 40 ${ }^{\text {th }}$ Anniversary Edition. Oxford: Oxford University Press. 